\title{
Covid-19 and the Brazilian Prison System: Criteria and Limits Imposed by Courts to Grant Liberty
}

\author{
Augusto Martinez Perez Filho \\ PhD in Constitutional Law from Faculdade Autônoma de Direito - FADISP. Masters of Law - LLM from \\ Brigham Young University (EUA). Master of Law from Universidade Estadual Paulista "Júlio de Mesquita \\ Filho" - UNESP. Professor at Universidade de Ribeirão Preto - UNAERP and Universidade de Araraquara - \\ UNIARA \\ Marilda Franco de Moura \\ Post Doctorate from Universidade do Porto - FLUP (Portugal). PhD in Letras from Pontifícia Universidade \\ Católica - PUC/SP. Licensed in Letras and International Trade. Professor at Centro Universitário "Barão de \\ Mauá" \\ Renato Simão de Arruda \\ Currently enrolled as student at Executive Master of Law from Universidade de Araraquara - UNIARA. Lawyer
}

\begin{abstract}
The pandemic caused by COVID-19 (Sars-CoV-2) reshaped all manners of acting and dealing with situations involving the rulings within the Brazilian prison system. Renewing the prior declaration by the Brazilian Supreme Court "unconstitutional state of affairs", with the reiterated violation of human rights, the current scenario has revealed inconsistencies of judicial rulings in face of similar situations, corroborating to mitigate legal security.Brazilian prisons already have issues related to overcrowding and fragility - and in many cases to necessary care regarding social reintegration of those who pass through the system. However, in addition to the already existing contagious outbreaks within Brazilian prisons, the new coronavirus has amplified the challenge on the Judiciary, which must ensure - at the same time - the health of those who are deprived of their liberty and determine guidelines that provide legal parameters to decisions in times of unusual crisis, such as ones experienced during a pandemic.For this reason, there is a need to establish parameters for granting or denial of liberty. The Nacional Council of Justice (CNJ) issued the Recommendation n. 62/2020, providing guidelines to judicature regarding prevention against the COVID-19 mass infection within the scope of Brazilian prison system. The recommendation adopted criteria about imprisonment reality, virus dissemination speed and the conditions of prison premises, therefore proposing, in some cases, the flexibility of custody or transfers to other units.However, despite of this normative direction, an analysis of judicial decisions issued on habeas corpus, including the Brazilian Federal Supreme Court, reveals the lack of uniformity among judicature, which does not corroborate to achieve the purposes sought by the CNJ, as well as demeaning the fundamental right to equality foreseen in our legal system. The present assay analyses the variability of decisions issued by the judicature, utilizing the online database of The Justice Court of São Paulo, for it is the largest State Court in Brazil in numbers of cases involving imprisonment, as well as decisions issued by the Brazilian Superior Court of Justice and the Supreme Court, identifying the different criteria adopted, in order to demonstrate the lack of legal security, inviting into a reflection of whether the Brazilian Judiciary is effectively meeting its final purpose: to produce social pacification.
\end{abstract}

Keywords: Prison System; Covid-19; Habeas Corpus; Brazilian Courts; Criteria.

DOI: $10.7176 /$ RHSS/11-11-03

Publication date:June $30^{\text {th }} 2021$

\section{Introduction}

The present work aims to empirically analyze the criminal policy applied by the Courts for the decree and maintenance of prisons, precautionary or definitive, in times of pandemic, decreed on March 11th, 2020, by the World Health Organization, when emergency measures started to be taken to prevent the virus spread ${ }^{1}$.

In Brazil, social isolation was established as a measure to prevent contamination. There was a need to avoid the gatheringof people and, in view of the virus high contagiousness, the Courts have suspended service to

\footnotetext{
${ }^{1}$ Brazil declared a Public Health Emergency of National Importance (Emergência em Saúde Pública de Importância Nacional - ESPIN), through the Ordinance $n^{\circ} 188 / \mathrm{GM} / \mathrm{MS}$; the Ministry of Health and the state governments recommended a series of measures to prevent the spread of the virus, with the main caveat to avoid agglomerations; in the state of São Paulo - among many other administrative measures teleworking for the elderly, pregnant women and people with chronic respiratory diseases, heart disease, diabetes, hypertension or other conditions that depress the immune system was instituted; museums, libraries and cultural spaces were closed; public events have been suspended since the day 16.03.20; state schools were closed and classes suspended; finally, there is a restriction of access to public bodies, with regulation of the flow of people (according to State Decrees $n^{\circ} 64.862$ e 64.864).
} 
society, listing measures that have been in effect untill now. (CSM, 2020)

Due to these measures and, mainly, to the degree of lethality present with greater intensity - according to health experts - in certain groups, called "risk group", defense and / or protection entities to the person deprived of their liberty, called for adoption of preventive measures also within the prison system. As an example we mention the Institute for Defense of the Right to Defense, which, on March 16th, 2020, submitted to the Federal Supreme Court in the Claim of Non-compliance with a Fundamental Precept $n^{\circ} 347 / 15$, incidental precautionary measure, requiring the granting of house arrest to those who are part of the so-called risk group. (STF, 2020)

When analyzing the incidental measure, Justice Marco Aurélio de Mello rendered a decision in which he called on the Criminal Execution Courts, due to the COVID-19 pandemic, to analyze the procedural measures to be examined with greater urgency:

a) probation to prisoners aged 60 or over, pursuant to Article 1 of Law No. 10,741, of October 1st, 2003;

b) house arrest for HIV-positive people, diabetics, people with tuberculosis, cancer, respiratory, cardiac, immunosuppressive or other diseases that may be aggravated by contagion by COVID-19;

c) house arrest for pregnant and lactating women, pursuant to Law No. 13,257, of March 8th, 2016 Statute of Early Childhood;

d) house arrest for prisoners of crimes committed without violence or threat of immediate force;

e) replacement of provisional arrest by an alternative measure due to crimes committed without violence or threat of immediate force;

f) alternative measures for prisoners caught in the act of committing crimes without violence or a threat of immediate force;

g) progression of punishment term to those who, having met the temporal criterion, awaits a criminological examination;

h) early progression of punishment to individuals submitted to the semi-open regime.

The rapporteur further determined that his decision was referred to na en banc session to be endorsed. However, the highest body of the Federal Supreme Court, denied referendum to the rendered decision, which stopped producing effects.

Notwithstanding the discussion of the matter in the Supreme Court, on March 3rd, 2020, the National Council of Justice (CNJ) issued the Recommendation $\mathrm{N}^{\circ} 62 / 20$, where it was established the guidelines to be met by the Courts of Justice, when dealing with the matter regarding individual liberty, while the state of public calamity is present. (BRASIL, 2020)

In summary, the CNJ recommendation provided guidance on the adoption of preventive measures for the COVID-19 infection spread within the prison system and the socio-educational system facilities, establishing a reduction in the inflow of people into these systems; the preventive measures in conducting hearings; the exceptional suspension of custody hearings, maintaining the necessary analysis, by the Judiciary Branch, of the ocurred in flagrente delicto arrests; and the joint action with the entities of the Executive Branch and the Secretaries of Penitentiary Administration of States.

Another issue addressed in the refered Recommendation was maintaining the health of people deprived of their liberty, especially due to the situation of confinement and overcrowding in Brazilian prisons, declared as an "unconstitutional state of affairs" by the Supreme Court. In the article 4 of the Recommendation, we see the guidelines on provisional detentions, recommending the judicaturein the prejudgment phase, the reevaluation of provisional detentions, especially of pregnant women, breastfeeding women, mothers of children up to twelve years of age or of a person with disabilities, doing time in institutions with occupation greater than capacity or without health staff and people whose preventive detentions have exceeded the period of ninety (90) days. The said article also prescribes the maximum exceptionality in the decree of new preventive detentions. (STF, 2020)

However, article 5 of Recommendation No. 62/20 provides guidance to judicature with jurisdiction on criminal execution proceedings, for anticipation of release from closed and semi-open regimes and the grant of house arrest, respecting the precedents of the Brazilian Constitutional Court.

Finally, article 6 sets forth the application of house arrest, in cases of civil arrest, also seeking to reduce the epidemiological risk.

Although it is a recommendation, the purpose of the measure is to establish an exceptional criminal policy due to the pandemic, and it must guide the conduct of the judicature for the situations therein described. Moreover, as will be seen below, the Judiciary branch has not been following the CNJ guidelines, corroborating - to a certain extent - to the increase the lack of legal insecurity.

\section{The purpose of the Criminal Policy established in CNJ Recommendation No. 62/20}

It can be said that the guidance advocated by the CNJ, in the recommendation under discussion, seeks to bestow privilege upon the fundamental right to life in relation to serving a sentence resulting from a criminal offense, in a genuine exercise of balancing constitutional guarantees.

Taking into account the premise adopted by public authorities that isolation is the best way to combat the 
spread of the virus, the CNJ decided, as a matter of course, to recommend the release of individuals who committed non-violent crimes and are serving a semi-open regime, as well as avoiding new arrests, as a way to minimize the risk of contact, avoiding the spread of the disease in the prison system, where health care is precarious and unable to absorb a massive demand.

This conclusion was drawn by the Supreme Court of the country, which, in the ruling of the Claim of Noncompliance with a Fundamental Precept (Arguição de Descumprimento de Preceito Fundamental - ADPF) No. 347, acknowledged the "unconstitutional state of affairs" in the Brazilian prison system, acknowledging the failure of the prison system, the offense to several constitutional principles, (such as the International Covenant on Civil and Political Rightsand the Convention against Torture, in addition to the Criminal Execution Law itself) and the problems, both in the formulation and implementation of public policies. (STF, 2020)

The Rapporteur stated that "it is evident the problem of overcrowding, which can be the source of all ills", pointing out that most inmates are subject to conditions such as overcrowding, torture, homicide, sexual violence, unclean or unhealthy cells, proliferation of infectious diseases, unfit food, lack of drinking water, basic hygiene products, access to legal aid, education, health and work. (BRASIL, 2015)

Therefore, the CNJ intended to fill this gap when issued Recommendation No. 62/20, establishing a criminal policy of prevention and risk reduction, given the real and collapsed situation of the prison system.

In the same vein, the National College of General Defenders (Colégio Nacional dos Defensores Gerais CONDEGE) required the President to exceptionally grant general pardon for elderly and disabled people, as well as for convicted women, for they are part of the so-called "risk group", in addition to prisoners serving sentences in overcrowded facilities, and individuals convicted of crimes of drug trafficking and the establishment of a humanitarian pardon. (ANGELO, 2020)

Among the arguments used by CONDEGE, it was mentioned that:

It is public knowledge that the most efficient measure to prevent the spread of the virus that causes COVID-19 is the isolation and prohibition of gatherings in closed and unventilated places, measures that are impossible to be enforced in a prison system that has an averege overcrowding rate of $171 \%$. In addition to the overcrowding and difficulties in sanitizatizing prisoners and locations due to the lack of products, the Brazilian prison system facilities also present a ventilation problem that aggravates the spread of the virus. (CONDEGE, 2020)

Such statements, added to the other information elements described above, lead to the inevitable conclusion that the only way pointed out by the sanitary and health authorities to contain the spread of COVID-19 is isolation, thus "it is inevitable to admit that there is no way to contain the contagion among people who are in prison or work and move around in prisons. The only measure capable of mitigating the damage to public health arising from this situation is the reduction of the capacity of these establishments and the exclusion of prisoners and employees who are part of groups that are at greater risk to health and life" (CONDEGE, 2020)

This was the concern of the National Council of Justice (CNJ),

considering the high rate of transmissibility of the new coronavirus (COVID-19) and the significant worsening of the contagion risk in prisons and socio-educational facilities, taking into account factors such as the gathering of people, the unhealthiness of these units, the difficulties in ensuring compliance with minimum hygiene standards and rapid isolation of symptomatic individuals, insufficient health teams, among others, inherent characteristics to the "unconstitutional state of affairs" of the Brazilian prison system acknowledged by the Federal Supreme Court in the ADPF No. 347. (CNJ, 2020)

The Council guided the adoption of measures to decrease the prison population, but due to the position adopted in the study under debate, it was not granted by the great majority of Brazilian Justices.

\section{The (in) applicability of CNJ Recommendation No. 62/20 by our Courts}

In a study carried out with the São Paulo Court of Justice for the Superior Court of Justice and the Federal Supreme Court, the decisions rendered with legal support in CNJ Recommendation 62/20 were analyzed, in order to seek a better understanding on how the guidance contained therein has been applied -or not.

The methodology of the study consisted of documentary verification of the decisions issued by the aforementioned Courts, during the period between January 3rd, 2020 and June 30th,2020. It was sought to identify the arguments used by the judges in the leading cases, comparing them with the guidelines outlined by CNJ. The results will be presented below.

The Courts whose judgments were the object of analysis were chosen according to the following criteria:

a) TJSP - Court with the largest number of cases and with the largest prison population in the country;

b) STJ - Court immediately superior to the State Courts; and

c) STF - Supreme Court of the country. 
Having established this premise, what is intended hereinfter is to analyze the inconsistencies of the judicial decisions with the normative excerpts and the inconsistency of the judicial decisions before the aforesaid Courts.

\section{1 - The decisions rendered by the São Paulo Court of Justice (TJSP)}

The TJSP, the Court with the highest volume of cases in the entire country (SÃO PAULO, 2021), also emerges as the one that has analyzed the most petitions for Habeas Corpus (HC) based on CNJ Recommendation No. 62/20, among the State Courts. (TJSP, 2021)

For study porpuses, we analyzed numerous decisions, dismissing identical petitions and identifying the groundwork that guided such decisions.

Below, we are showing the study results related to the decisions refering to prisoners serving a sentence resulting from a condemnatory sentence, definitive or not, and to prisoners in provisional detention.

\subsection{1 - Petitions made in favor of provisional detaineés}

What we observed from analyzing the decisions that involved Habeas Corpus petitions based on CNJ Recommendation $62 / 20$, was the fact that the petitioners formulated their petitions solely based on the provisions of the regulations issued by the external control entities, without any demonstration that the arresteé was part of the risk group.

In general, such petitions were dismissed on the grounds that the recommendation is not a safe conduit for the indiscriminate granting of liberty. See:

Regarding the situation involving the Coronavirus pandemic - COVID-19, it is clear that there is no evidence in the processes that the arrestee belongs to a risk group or that he has a disease which prevents them from remaining imprisoned and, if necessary, receiving treatment inside the prison system, which is known to be equipped to do so in view of the adoption of sanitary measures designed for this purpose.

It is also worth noting, still, as recently decided by this respectable Criminal Chamber, that Recommendation No. 62 of the National Council of Justice, which deals with the pandemic caused by Covid-19, only provides certain measures, such as the re-evaluation of provisional detentions, under the terms of article 316 of the Code pf Criminal Procedure, in specific cases, but does not authorize the automatic and indiscriminate release of prisoners... (bold emphasis added)

Therefore, as the provisional custody is justified on the basis of specific elements of records and there are no reasons to justify modifying it or at least mitigating it, according to the case the illegal constraint invoked is not identified, being strict the dismissal of the order. (TJSP, 2020)

This is, therefore, one of the limits established by the TJSP, to enforce the CNJ Recommendation, that is, belonging to a risk group as a justifying requirement for accepting the petition. It is important to note, however, that there is no such express indication in the administrative regulations, for according to CNJ, pretrial detentions must be avoided at all costs, and should only be applied in extremely exceptional situations, duly grounded:

Article 4 - To recommend to the judges with jurisdiction for the criminal prejudgment phase that, in order to reduce the epidemiological risks and in compliance with local context of the virus spread, consider the following measures:

III - the maximum exceptionality of new provisional detention orders, observing the health authorities protocol. (CNJ, 2020)

It cannot be stressed enough that the pandemic affects everyone, and not just those who are in groups most vulnerable to the virus. For no other reason, the adopted isolation was not of the "vertical" type, but "horizontal", with strong adherence by the TJSP itself, prohibiting municipal decrees that sought to anticipate the end of social isolation ${ }^{1}$.

However, in some cases, even when the arrestee belonged to the risk group, the petition for release was

\footnotetext{
${ }^{1}$ In view of the seriousness of the situation experienced in the country, the Judiciary of São Paulo, in the case files of Case No. 100001243.2020.8.26.0633, of the Itanhaém / SP District, granted an injunction restricting the access of tourists to the municipalities of Mongaguá, Itanhaém, Peruíbe, Itariri and Pedro de Toledo, while the state of emergency persists; the 14th Court of the Public Finance of the Capital granted an injunction, in the public civil action $\mathrm{n}^{\mathrm{o}}$ 1015344-44.2020.8.26.0053, authored by the Public Ministry, prohibiting religious cults in the Capital; in the Comarca de Iguape, case $\mathrm{n}^{\circ}$ 1000335-51.2020.8.26.0244, the Judiciary has determined the suspension of all non-essential activities and services, such as gyms, restaurants and commerce; the suspension of non-essential public services that cannot be performed through digital means or remote work; the ban on the entry of new guests into the hotel sector; among others; the Justice of the District of Ribeirão Preto/SP suspended, in the records of the case $\mathrm{n}^{\circ}$ 1012331-36.2020.8.26.0506, the Municipal Decree $\mathrm{n}^{\circ} 100 / 20$, which made social isolation more flexible, going against restrictions imposed by the Government in the face of the Covid-19 pandemic; in the same sense, the decision issued in case No. 2080564-34.2020.8.26.0000, of the District of Sertãozinho; the São Paulo Court of Justice has denied the request from the Municipality of Itararé, in the Civil Writ of Mandate No. 2092348-08.2020.8.26.0000, to resume normal activities; finally, following a request from the Union of Prison Agents of the State of São Paulo, he suspended visits to all prisons in the State, as can be seen in the Writ of Mandate No. 1015074-20.2020.8.26.0053. Accessed on May 29, 2020
} 
dismissed on the grounds that the prison institution where they are being held has adopted the preventive measures necessary to combat the spread of the virus. (TJSP, 2020)

It is a clear opposition to the criterion adopted by the TJSP itself for petitions granted based solely on the Recommendation (businesses cannot function to avoid gathering of people, due to the risk; but for the inmate, if there is no comorbidity, is there no risk with the overcrowding?).

In a certain case, although a risk group member, the arrestee was not entitled to the application of the Recommendation, because they did not meet its requirements, since they were provisionally detained for a crime committed with the use of violence or threat of immediate force. (TJSP, 2020)

It is a crime of grand robbery, with violence and a threat of immediate force in its essential elements. In this case, the defendant, in theory, acting in co-perpetration with another individual, subtracted a cell phone by means of a threat of immediate force from words and simulation of firearm use,. According to the findings, while the robbers approached the victim Jennifer, the witness Diego Ferreira noticed the action and engaged into a corporal fight with the individuals, so that the accused Diego dos Santos Alves was immediately arrested. In this context, it is clear that the liberty of the indicted, of evidente danger, threatens public order and can encourage new crimes, in addition to causing an extremely damaging repercussion to the social environment, already outraged with the true 'jungle' into which the great metropolises have become.

Furthermore, I also understand that, in the specific case, the granting of provisional release or precautionary measures is not seasonable. This is because such benefits should only be applied when useful and necessary for the intended purposes, so that, analyzing the circumstances of the fact and personality of the agent, in fact, these elements have already been duly appreciated at the time of prison sentence, unquestionable to say which are not sufficient when it considered the specific facts of case, under penalty of violating the principle of proportionality in the prohibition of infra protection modality.

I note, opportunely, that CNJ recommendation No. 62/2020, issued on March, $17^{\text {th }}$, 2020 in its $4^{\text {th }}$ paragraph, I, ' $c$ ', sets forth the need to reassess the maintenance of pretrial detention for cases exceeding 90 days or for cases not related to violence or threat of immediate force, not being the case under analysis. Thus, contrary to what it may seem, it does not serve as a safe-conduct to the indiscriminate release of prisoners. (bold emphasis added)

Therefore, I DENY the request made by the defense and ratify the understanding for maintaining the pretrial detention of the defendant on the same grounds previously exposed".

(TJ-SP - Habeas Corpus $\mathrm{n}^{\circ}$ 2067000-85.2020.8.26.0000 SP, Rapporteur França Carvalho, DJ: 26.05.20, $13^{\mathrm{a}}$. Criminal Law Chamber)

In another decision, due to the impossibility of presenting a medical report concerning the arresteé's illness, the medical examination by the prison unit professional had been requested within petition for a writ of habeas corpus. However, the petition was dismissed, on the grounds that in the context of an autonomous impugnation action, the evidence must be pre-constituted. (TJSP, 2020)

The question that arises is how it would be possible to carry out this expert report, needed to prove the preexisting disease, if the entire hospital apparatus was prepared to face COVID-19. In fact, this was one of the reasons for the isolation, which is to avoid the collapse of the Brazilian Unified Health System (Sistema Único de Saúde - SUS). It should also be noted that not every prisoner is able to hire a private doctor to assess them in prison.

The decisions analysis showed that, without evidence of pre-existing disease including the arresteés in the risk group, such request would have little chance of success.

It is interesting to notice that, based on the Habeas Corpus $\mathrm{n}^{\circ}$ 2053167-97.2020.8.26.0000 analysis, the $5^{\text {th }}$ Chamber of the TJSP (2020) prescribed rules to verify the admissibility of the order, in petitions related to the pandemic. In his vote, Rapporteur TRISTÃO RIBEIRO clarified that the outbreak of the pandemic does not imply, in its own, the automatic admission of the arrestee under house arrest, and it is also necessary to meet the requirements below:

a. indication of health authority for the release of prisoners, provisional or not;

b. information that they belong to a risk group; 
c. medical documentation pointing to the current need for differentiated health care;

d. demonstration that there is an effective risk, in the facility where they are found, greater than that borne by not imprisioned individuals to acquire the disease;

e. evidence that in an open environment they will receive a more adequate medical care than the one provided by the state; and, in parallel,

f. because it has not been shown that the State, in the direct or indirect domain of penitentiary administration, has no means of promptly offering treatment, in the event of possible infection by the new COVID-19, in compliance, also, with the legal rule expressly provided for in article 41, item VII, of the Criminal Execution Law, guaranteed by article 5, item XLIX, of the Federal Constitution.

Below are the analyzed cases whose release was dismissed in the course of Habeas Corpus, relating it to the criminal type perpetrated by the inmate:

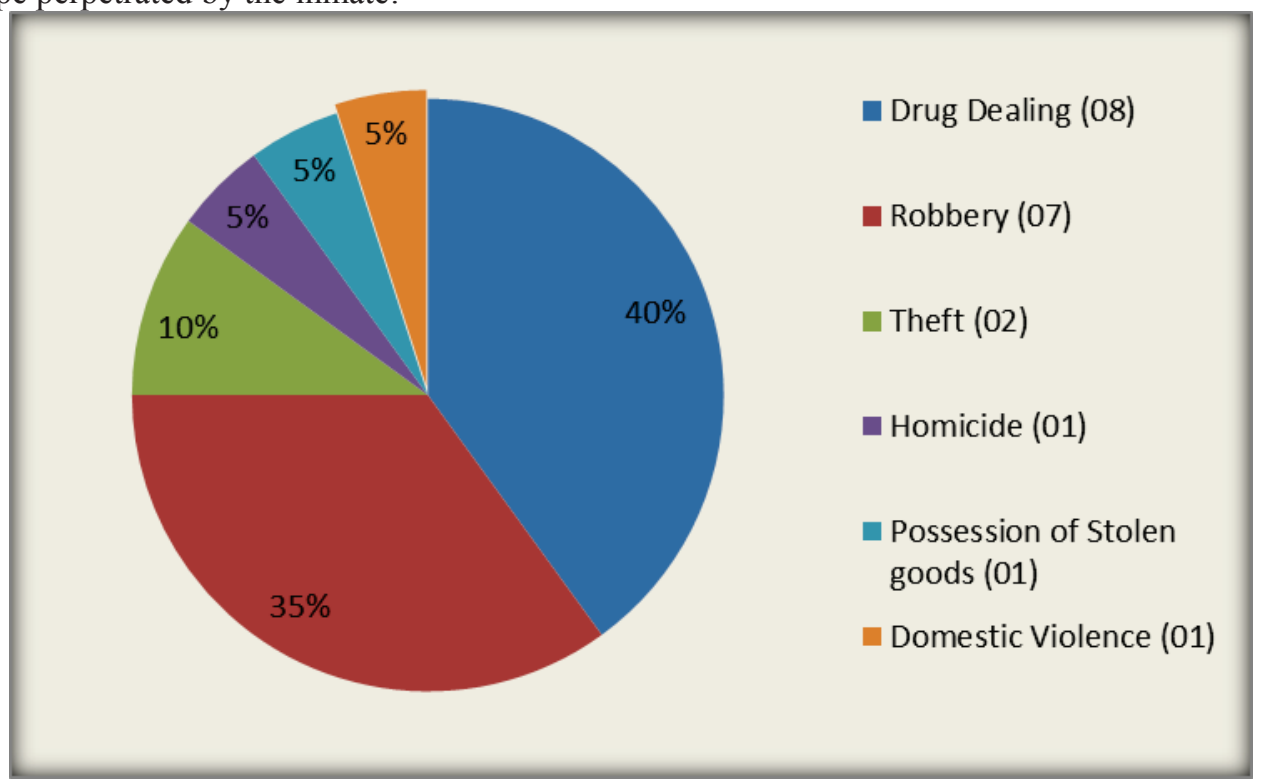

Figura 1 In this field, 20 (twenty) Habeas Corpus, each square is equivalent to one action, to gauge the number of decisions by type of crime

On the other hand, in the cases where the order was granted, only 05 (five) out of the 12 (twelve) who were granted the release $(41.66 \%$ of the total) proved to be part of the risk group.

The most used argument for granting petitions was that the pandemic situation cannot be ignored. In this regard:

Habeas Corpus. Reception.. Claim seeking the repeal of the preventive custody of the arresteé, with the issuance of a release order for their benefit. Applicability. The conduct attributed to the arresteé, which presents criminal reiteration for the practice of threat and compound larceny, does not reveal a severity compatible with the provisional detention. It cannot be ignored, however, the singularity of the pandemic situation caused by the new coronavirus, seemingly negligible, in casu, the maintenance of the provisional custody. Imposition of provisional measures other than prison. Order partially granted. (bold emphasis added)

(TJ-SP - Habeas Corpus n 2073940-66.2020.8.26.0000 SP, Rapporteur Guilherme de Souza Nucci, DJ: May/27/20, 16th. Criminal Law Chamber)

It is worth mentioning the decision rendered by Habeas Corpus $\mathrm{n}^{\circ}$ 2053356-75.2020.8.26.0000, in which the order for the arrestee to remain under house arrest was granted, while the pandemic lasts, and they should return to prison as soon as the isolation is over in the State. (TJSP, 2020)

Another decision worth mentioning was the one issued at Habeas Corpus No. 2073165-51.2020.8.26.0000, which granted house arrest to the arresteé under the argument that the impossibility of reconciling external work with the semi-open regime was demonstrated (TJSP, 2020), and that denying house arrest causing the arresteé to lose his job violates the principle of reasonableness and deviates from the primary objective of execution, which is the resocialization of the convict ${ }^{1}$.

\footnotetext{
${ }^{1}$ It is noted that in recent past, Brazilian jurisprudence has added efforts to minimize the effects of mass incarceration, with the adoption of criteria, subsequently positivized, for the substitution of pre-trial detention (arts. 318 and 318-A of the Criminal Procedure Code ) and compliance with an open regime in a private residence (art. 117, Law No. 7,210/84). In this sense Habeas Corpus Coletivo n ${ }^{\circ} 143641$ available in: $<$ http://www.stf.jus.br/portal/cms/verNoticiaDetalhe.asp?idConteudo=370152> Access in: 04.06.20.
} 
Cases under analysis whose release was granted in the course of Habeas Corpus (TJSP, 2020), divided by crimetype criteria:

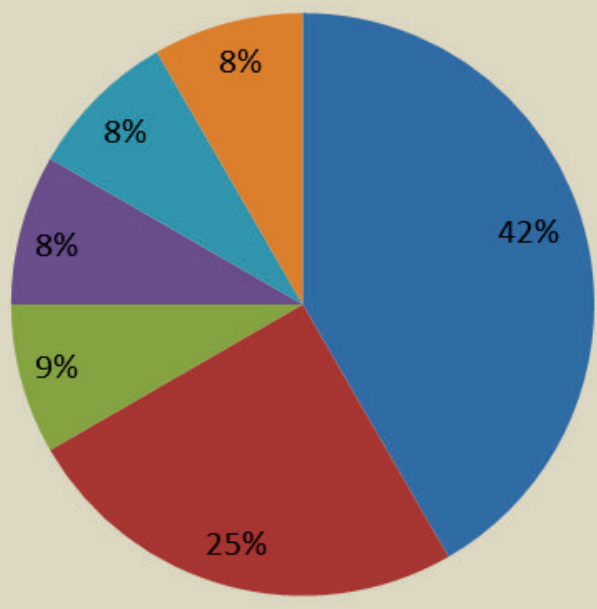

Drug Dealing (05)

Robbery (03)

Theft (01)

Homicide (01)

Possession of Stolen goods

(01)

Domestic Violence (01)

\section{Figura 2 In this field, 12 (twelve) Habeas Corpus, each square is equivalent to a crime-type, to gauge the} number of favorable decisions

It can be seen from the result described above, that release was granted in cases of crimes committed with violence or threat of immediate force ( 01 homicide, 01 robbery, and 01 domestic violence), even though there is no guidance in this regard in the CNJ Recommendation. This fact leads us to conclude that, in some cases, the release would be granted even without the presence of the pandemic, due to other matters invoked by the judicature in the rendered decision.

It cannot be said, therefore, that in these cases the release was granted exclusively as a way of avoiding imprisonment to minimize the risk of spreading COVID-19.

\subsection{2 - Petitions made in favor of prisoners already convicted ${ }^{1}$}

In the field of rendered decisions in criminal execution proceedings, what was outlined as a major basis for the dismissal of petitions was the statement that CNJ Recommendation $\mathrm{N}^{\circ} 62 / 20$ is not a cogent rule, that is, it is not compulsory.

Another common argument in dismissal decisions is that the penal institutions have adopted measures to prevent the spread of the disease and that they are able to provide adequate treatment to arresteés, even though some belong to the risk group.

HABEAS CORPUS. Criminal Execution. Intention to reverse a decision which dismissed a petition to grant a prison sentence in house arrest regime - Nonsuit arresteé convicted of a serious crime (drug trafficking) and still serving a sentence in a closed regime despite having chronic diseases (high blood pressure and diabetes), with a stable health status, at the present moment. Administration of the prison unit, which has already been taking actions to safeguard the inmate's physical integrity, who receives medical care four times a week and has access to all the necessary medicines, being asymptomatic - Panorama which, at least for now, does not justify the adoption of the exceptional measures provided for in Recommendation No. $62 / 2020$, of the CNJ.

(TJ-SP - Habeas Corpus n ${ }^{\circ}$ 2066658-74.2020.8.26.0000 SP, Rapporteur CESAR MECCHI MORALES, DJ: 23.05.20, 3rd. Criminal Law Chamber) (TJSP, 2020)

For these reasons, 66\% (22 out of 30) of the analyzed Habeas Corpus, which dealt with prisoners serving sentence, were dismissed.

It is interesting to note that in Habeas Corpus $\mathrm{n}^{\circ}$ 2087756-18.2020.8.26.0000, the Rapporteur (TJSP, 2020) added that the Department of Penitentiary Administration (Secretaria de Administração Penitenciaria - SAP) informed the TJSP Administrative Office of the Courts that it is taking all necessary measures to prevent the spread of COVID- 19 in the prison environment. It should be noted that there was no publication of the aforementioned communication, hindering the exercise of the right to a fair hearing, as lawyers did not have elements capable of sustaining the 'distinguishing' of situations involving their clients.

\footnotetext{
${ }^{1}$ Thirty (30) Habeas Corpus related to convicted persons were analyzed, of which 22 had their order dismissed and 08 had their order granted.
} 
However, the information is repeated in other decisions, such as in the case of Appeal in Criminal Execution No. 0006297-02.2020.8.26.0041 (TJSP, 2020), where the rapporteur adds: “...despite the circumstances and difficulties faced, the interior of the penitentiary system in São Paulo offers the necessary conditions for the protection of people deprived of their liberty, especially regarding the COVID-19 pandemic... (Official Letter sent by SAP to the Administrative Office of the Courts on April $8^{\text {th }}, 2020$, signed by the Secretary of Penitentiary Administration, Mr. Nivaldo César Restivo)".

As it appears from the rendered decisions, such communication was accepted as sufficient by the TJSP, as denoting the mitigation of contamination risk, and - consequently - to justify the dismissal of petitions.

On the other hand, some Rapporteurs adopted the factor - part of the risk group - as being sufficient for the approval of house arrest. In half of the orders granted (that is, 04 out of 08), it was mentioned that the arresteé belonged to the risk group, and the request for house arrest should be granted, pursuant to CNJ Recommendation $62 / 20$.

\section{2 - Decisions rendered by the Superior Court of Justice (STJ)}

The Superior Court of Justice, known as the Citizenship Court, was created by the Federal Constitution of 1988 with the responsibility to standardize the construction of federal law throughout Brazil, following the constitutional principles and the guarantee and defense of the Rule of Law.

The Superior Court is responsible for the trial of Habeas Corpus filed in relation to illegal constraint resulting from the acts of State Courts Justices ${ }^{1}$. And the controversy verified in the TJSP remains, also, in the decisions analyzed with the STJ's body of work of precedents.

The number of Habeas Corpus, analyzed by the STJ, in the period defined in this research, is staggering (BRASIL, 2020). Related to the theme of this article, we have the judgments rendered in Collective Habeas Corpus that, for the most part, were not heard.

The court dismissed Habeas Corpus No. 572.292 / AM (STJ, 2020) of the State Public Defender's Office (Defensoria Pública Estadual - DPE), which asked for the grant of house arrest regime to all prisoners in closed regime from Anísio Jobim Penitentiary Complex, members of Covid-19 risk group. The rationale for the decision referred to the lack of information from local authorities to protect members of the risk group from Covid-19, concerning the arresteés' clinical condition and the measures occasionally adopted to protect them from contagion or to treat them, if necessary.

Likewise, Habeas Corpus No. 567.779/CE, filed by the DPE-CE (STJ, 2020), which asked for liberty for all prisoners in the state that fit the guidelines of CNJ Recommendation No. 62/20; Habeas Corpus No. 571.796 / GO (STJ, 2020) which asked for the granting of house arrest regime for all inmates in the state who were in the open and semi-open regimes, and also for those in closed regime who were part of the so-called "risk group" defined in the aforesaid Recommendation; Habeas Corpus No. 570.440 / DF (STJ, 2020), filed by the Public Defender's Office (DPU) in favor of all people arrested or who would be arrested and who are in the Covid-19 risk groups; Habeas Corpus $\mathrm{n}^{\circ} \mathrm{s}$ 575.315/SP and 574.978/SC of DPE-SP and DPE-SC respectively (STJ, 2020), which asked for the early release or the granting of a house arrest regime for all elderly inmates from Odon Ramos Maranhão Penitentiary, in Iperó/SP and house arrest for people imprisoned in Florianópolis/SC, who are subject to the semi-open regime and would meet the time requirement for progression within the next 06 months.

In two collective petitions, however, the order was granted by Justice Sebastião Reis Júnior. In the first case (Habeas Corpus $\mathrm{n}^{\circ}$ 568.593/ES), he granted the order to release the provisional prisoners who, although setting bail in their favor, did not make the payment of the fixed amount. According to the Justice:

In view of what the National Council of Justice recommends in its resolution, keeping the investigated in prison is not proportional, solely because of the nonpayment of bail, since the cases - notably less serious - do not reveal the indispensable exceptionality required for the preventive decree.

In the second case (Habeas Corpus $\mathrm{n}^{\circ} 575.495 / \mathrm{MG}$ ), he granted prisoners the right to house arrest in two prisons in the city of Uberlândia/MG. In his decision, the Justice stated:

It seems to me, in this preliminary judgment, that there is an illegal constraint inrevoking the benefits granted to the reformed ones, listed in the initial petition, especially in view of the resurgence of the situation in which they were executing the sentence, all under semi-open regime, evolved to the less rigorous condition, working and already in contact with society.

\footnotetext{
${ }^{1}$ As provided in art. 105, item I, item 'c', of the Constitution, whose wording states that "it is the Superior Court of Justice (I) to process and judge, originally ('c') habeas corpus, when the coorator or patient is any of the people mentioned in item 'a' (in common crimes, the Governors of the States and the Federal District, and, in these and those of responsibility, the judges of the Courts of Justice of the States and the Federal District, the members of the Courts of Accounts of States and Federal District, Regional Federal Courts, Regional Electoral and Labor Courts, members of Councils or Courts of Accounts of Municipalities jurisdiction, Minister of State or Commander of the Navy, Army or Air Force, except for the jurisdiction of the Electoral Justice".
} 
As for individual actions, an observation point deserves to be highlighted, due to the number of petitions made to the Superior Court, which were not even known, due to the alleged "suppression of instance ". In these situations, petitions - with rare exceptions - were preliminary denied ${ }^{2}$, in a monocratic decision (08 actions).

In order not to be aware of the appeal, the offense to precedent 691/STF (BRASIL, 2003) was raised, which prevents the Superior Court from hearing the appeal when it is filed in relation to the preliminary decision of the State Court.

Another 13 Habeas Corpus $^{3}$ had their writ denied and another 11 had their injunction dismissed due ${ }^{4}$ to failure of meeting the requirements provided for in CNJ Recommendation 62/20.

Another $04^{5}$ habeas corpus had the injunction dismissed, even though it was acknowledged that the arresteé was part of the risk group. In these situations, the decisions show similarity in the argument that the Department of Penitentiary Administration has adopted the appropriate precautions and that the CNJ Recommendation is not mandatory, and the judicature is responsible for analyzing its application, according to the specific case.

Finally, 20 habeas corpus were accepted, 18 by final decision ${ }^{6}$ and 02 on preliminary injunction ${ }^{7}$. Among the grounds used to support the granting of the writ, we see the exceptionality afirmation of provisional detention in these times of pandemic (CNJ, 2020), health risk or spread of the virus and, meeting the requirements set forth in the CNJ Recommendation. Worthy of special mention is Habeas Corpus No. 570.608/SP (STJ, 2020), whose release was granted to a 23-year-old girl, on the grounds that the CNJ Recommendation also applies to people outside the risk group. The graphic below represents the decisions rendered by the Superior Court of Justice, objectively demonstrating the result of the carried out research:

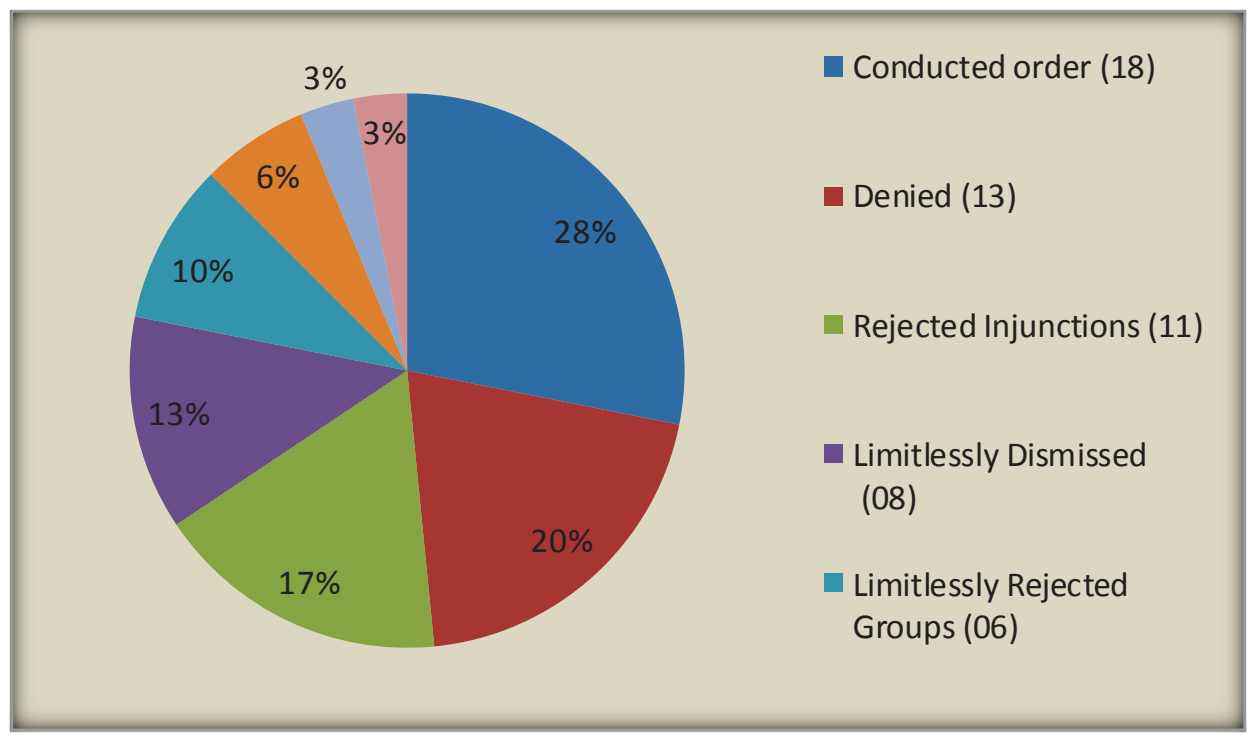

Figura 3 Indicates the type of results garanted by Superior Court of Justice on habeas corpus filled based on the pandemic argument and risks involved

\section{3 - Decisions rendered by the Federal Supreme Court (STF)}

Just as the TJSP, the Supreme Court created a portal regarding the actions arising from COVID-19. Regarding habeas corpus, the STF mentions rendering 6.946 decisions (STF, 2021), of which 3.750 were related to not known orders or with denied hearing; 724 decisions in which the writ was denied; 529 decisions in which the injunction was granted and 90 decisions in which the writ was granted.

The preliminary dismissals, as also seen in the STJ decisions, result from the application of Precedent 691/STJ, which prevents the judgment of an appeal filed in relation to the lower court preliminary decision. Illustrating the decisions on the issue, we have collected an understanding made by Justice Gilmar Mendes (STF, 2020), who proclaimed as follows:

\footnotetext{
${ }^{1}$ Defined by the Doctrine as a technical impropriety the jurisprudential understanding of Courts, of which it is not known of habeas corpus whose thesis has not been submitted to the scrutiny of the co-authoritative authority.

${ }^{2} 64$ decisions were analyzed, of which $08(12.5 \%)$ were rejected outright, that is, they did not know about the habeas corpus filed.

${ }^{3}$ Cases in which the merit of the petition was assessed, but denied the order.

${ }^{4}$ Cases in which the merits of the petition have not yet been assessed, but in a preliminary analysis, the request for freedom was rejected. In this situation, the deed will be sent for judgment by the collegiate body.

${ }^{5}$ Cases in which, even if the patient is in the risk group, the injunction was rejected, and the fact will be sent to the collegiate body for judgment.

${ }^{6}$ Cases judged where the order was granted.

${ }^{7}$ Cases in which the injunction was granted and awaits the final judgment by the collegiate body.
} 
the precedents of this Court abides by the reasoning of the inadmissibility of the filing of habeas corpus in the causes of its original jurisdiction, against a denial of a preliminary injunction in an action of the same nature filed before a higher court, before the writ's final judgment. According to precedent: Habeas Corpus (QO) 76.347/MS, Rel. Justice Moreira Alves, First Class, unanimous, DJ 8.5.1998; Habeas Corpus 79.238/RS, Rel. Justice Moreira Alves, First Class, unanimous, DJ 6.8.1999; Habeas Corpus 79.776/RS, Rel. Justice Moreira Alves, First Class, unanimous, DJ 3.3.2000; Habeas Corpus 79.775/AP, Rel. Justice Maurício Corrêa, Second Class, majority, DJ 17.3.2000; and Habeas Corpus 79.748/RJ, Rel. Justice Celso de Mello, Second Class, majority, DJ 23.6.2000. And more recently: Habeas Corpus-AgR 129.907/RJ, Rel. Justice Carmen Lúcia, Second Class, unanimous, DJe 13.10.2015; Habeas Corpus-AgR 132.185/SP, reported by me, Second Panel, unanimous, DJe 9.3.2016; Habeas Corpus 133.158 / DF, Rel. Justice Dias Toffoli, DJe 11.3.2016; and Habeas Corpus 133.287/DF, Rel. Justice Luiz Fux, DJe 7.3.2016. This conclusion is represented in Precedent STF 691, "in verbis": It is incumbent upon the Supreme Federal Court to hear the habeas corpus filed against a decision of the Rapporteur who, in habeas corpus filed in a higher court, dismiss the injunction". (STF, 2020)

In the same vein, Habeas Corpus No. 183.014/PA. In three decisions, despite having no knowledge of habeas corpus, the writ was granted ex officio (STF, 2020), as it can be seen in habeas corpus $n^{\circ} 182.950 / \mathrm{SP}$, and 183.578/SP by Justice Ricardo Lewandovski and $n^{\circ} 184.010 /$ RS by Justice Edson Fachin. And the decisions mention that the grounds presented by the lower court judge are generic and abstract, not meeting the need to motivate judicial decisions or are contrary to the guidelines proposed by CNJ, justifying the granting of habeas corpus, "ex officio".

Other habeas corpus, which were dismissed as a preliminary matter, relied on the rapporteur's (STF, 2020) determination to issue an official letter to the execution court, for "re-analysis of the preventive detention of the arrestee in the light of CNJ Recommendation 62/2020, taking into account the particularities of the specific case" (elderly arresteé - 61 years old - who has health problems, such as skin lesions compatible with skin cancer and hypertension).

In cases where the preliminary injunction was denied, the common ground refers to the lack of evidence of a pre-existing disease or to the demonstration of confirmed or suspected cases in the prison unit and that the health crisis resulting from the pandemic, alone, is insufficient to accept the petition. (STF, 2020)

Finally, in the cases in which the order was granted, the basic ground was the meeting of CNJ Recommendation requirements, in case of elderly and diseased arresteés - which increase the risk of death in case of contamination. In this respect, the decisions rendered in Habeas Corpus No. 182.596/ES and 182.886/SP. (STF, 2020)

\section{Conclusion}

It is inferred from the research work that, although the CNJ Recommendation contains specific guidelines, they have not been followed in many decisions, and it is emphasized, at several moments, that it is not a mandatory rule and not applied to the convenience of the judge. What has been demonstrated is that for certain judges, their recommendation should be respected and, for others, it was not applicable, even if the inmate meets its requirements.

In addition, there is a clear recognition of the degrading condition faced by the imprisoned and the risk of contamination and spread on a large scale is expressly acknowledged. But even so, the social isolation advocated for society does not have the same treatment when the prison population is the end receiver.

Clearly, the Judiciary diverts the confrontation of the issue to secondary issues such as the existence of a health sector within the institutions, as an argument for maintaining the prisoner. Even

considering the state of grave vulnerability in which the person deprived of liberty finds themselves in and the responsibility that falls on the Satate shoulders to care for these people from whom it takes outpatient care liberty (and so many other rights), it is inadmissible the abandonment and insufficient assistance conferred to this issue. Respect and attention to the health of the prison population deserves a prominent position not only because of the possible impacts that prison diseases can have on the health of society in general (in the case of a penalty transcendence), but because it is, above all, a condition for maintaining a minimally dignified existence for those imprisoned individuals. (BRASIL, 1988)

In many cases, overcrowding and degrading conditions are disregarded, without any respect for human dignity. This is because, as informed by the Departamento Penitenciário Nacional, the Brazilian prison system 
has more than two thousand (2,000) contaminated inmates and forty-nine (49) deaths (DEPEN, 2021). Taking into account the transmitting potential of the virus, as well as the geometric progressivity, it can fatally reach thousands of inmates who cannot isolate themselves due to the way incarceration is carried out ne in the country (overcrowding and high level of unhealthiness).

Thus, the conclusion resulting from the carried out wok is that the judiciary branch acts with too much subjectivism and ends up creating conflicts - whereas the standardization of superior decisions would reduce the discretion of the first degree magistrates, reducing the large number of habeas corpus filed to Courts - and for spreading the feeling of legal insecurity, with evident offense to the principle of equality, judging equal cases differently and turning the luck factor - distribution of the feat to the rapporteur who has applied the Recommendation - as a differential element in the criminal policy application laid down by the CNJ.

\section{References}

ANGELO, Tiago. Defensores públicos pedem que Bolsonaro indulte presos para conter coronavírus. 2020. Disponível em: https://www.conjur.com.br/2020-mar-19/defensores-publicos-pedem-bolsonaro-indultopresos. Acesso em: 15 fev. 2021

BRASIL. Colégio Nacional de Defensores Públicos Gerais. Petição. 2020. Disponível em: defensores-publicospedem-bolsonaro.pdf (conjur.com.br). Acesso em: 15 fev. 2021.

BRASIL. Conselho Nacional de Justiça. Recomendação $\mathrm{n}^{\circ} 62 / 20$ de 17.03.20. Disponível em https://atos.cnj.jus.br/atos/detalhar/3246 Acesso em 28.05.20.

BRASIL. Constituição (1988). Constituição Federal nº Art. $1^{\circ}$, inc. III, de 1988. . Brasília, DF.

BRASIL. DEPARTAMENTO PENITENCIÁRIO NACIONAL. . Medidas de Combate ao COVID-19. Disponível https://app.powerbi.com/view?r=eyJrljoiYThhMjk5YjgtZWQwYS00ODlkLTg4NDgtZTFhMTgzYmQ2M GVlIiwidCI6ImViMDkwNDIwLTQ0NGMtNDNmNy05MWYyLTRiOGRhNmJmZThlMSJ9. Acesso em: 15 fev. 2021.

BRASIL. SUPERIOR TRIBUNAL DE JUSTIÇA. . Mais de 180 mil decisões foram proferidas pelo STJ desde 0 início do trabalho remotor Disponível em: https:/www.stj.jus.br/sites/portalp/Paginas/Comunicacao/Noticias/Mais-de-180-mil-decisoes-foramproferidas-pelo-STJ-desde-o-inicio-do-trabalho-remoto.aspx. Acesso em: 15 fev. 2021

BRASIL. Superior Tribunal de Justiça. Habeas Corpus n: 567.457/DF; 567.821/SP; 567.782/SP; 568.214/DF; 570.398/PR; 565.799/RJ; 567.006/SP; 550.529/SP; 567.961/SC; 558.308/PR; 568.590/SP; 569.392/SP; 567.994/SC; 563/142/SE; 574.283/MG; 577.263/PR; 577.996/MG; 570.608/SP; 584.317/SC; 584.488/MG; 584.432/MG; 584.413/SP; 584.565/SP; 584.496/PI; 584.449/SP; 584.408/SP; 584.374/SP; 584.118/SP; 569.583/SP; 569.650/RJ; 542.381/SP; 574.627/SP; 568.436/GO; 575.241/SP; 556.165/DF; 576.333/RS; 570.970/AC; 542.381/SP; 570.608/SP; 570.440/DF; 571.796/GO; 584.253/MS; 584.232/SP; 584.167/MG; 584.088/RS; 583.974/PR; 583.941/SP; 583.914/SP; 583.868/SP; 583.855/MG; 583.610/SP; 582.518/SP; 584.475/SP; 584.245/RS; 583.533/RN; 584.406/SP; 572.292/AM; 567.779/CE; 575.315/SP; 574.978/SC; 568.593/ES; 575.495/MG; 568.593/ES; e 575.495/MG. Disponível em: <https://scon.stj.jus.br/SCON/> indicando o número do recurso no campo de pesquisa especifica. Acessos em 11.06.20

BRASIL. Supremo Tribunal Federal. ADPF $n^{\circ}$ 347/15. Disponível em: <disponível em: $<$ http://www.stf.jus.br/portal/peticaoInicial/verPeticaoInicial.asp?base=ADPF\&s1=347\&processo=347> Acesso em 29.05.20.

BRASIL. Supremo Tribunal Federal. Adpf $n^{0}$ 347. Relator: Marco Aurélio. Brasília, DF, 09 de setembro de 2015. Diário Oficial da União. Disponível em: http://portal.stf.jus.br/processos/detalhe.asp?incidente=4783560. Acesso em: 12 fev. 2021.

BRASIL. Supremo Tribunal Federal. Habeas Corpus nº:182.596/ES; 182.886/SP; 183.582/SP; 183.662/SP; 185.912/MG; 183.014/PA; 177.528/RJ; 182.950/SP; 183.578/SP; 184.010/RS; e 143.641/SP. Disponível em: $<$ http://portal.stf.jus.br/> indicando no campo de pesquisa da pagina inicial a classe do processo (HC) e o número do recurso. Acessos em 15.06.20.

BRASIL. Supremo Tribunal Federal. Súmula $n^{\circ}$ 691. Diário Oficial da União. Brasília, 13 out. 2003. Disponível em: http://www.stf.jus.br/portal/jurisprudencia/menuSumarioSumulas.asp?sumula=1480. Acesso em: 15 fev. 2021

BRASIL. Tribunal de Justiça de São Paulo. Habeas Corpus n ${ }^{\circ}$ 2058001-46.2020.8.26.0000; 206894085.2020.8.26.0000; 2066160-75.2020.8.26.0000; 2055107-97.2020.8.26.0000; 2069666-59.2020.8.26.0000; $2067000-85.2020 .8 .26 .0000 ; \quad 2070256-36.2020 .8 .26 .0000 ; \quad 2061487-39.2020 .8 .26 .0000 ; \quad 2060345-$ 97.2020.8.26.0000; 0013624-24.2020.8.26.0000; 2086354-96.2020.8.26.0000; 2072633-77.2020.8.26.0000; 2053167-97.2020.8.26.0000; 2055643-11.2020.8.26.0000; 2061745-49.2020.8.26.0000; 206853112.2020.8.26.0000; 2058035-21.2020.8.26.0000; 2073763-05.2020.8.26.0000; 2057044-45.2020.8.26.0000; 2064452-87.2020.8.26.0000; 2053438-09.2020.8.26.0000; 2027398-87.2020.8.26.0000; 2079020- 
11.2020.8.26.0000; 2064298-69.2020.8.26.0000; 2068741-63.2020.8.26.0000; 2073940-66.2020.8.26.0000; 2011096-80.2020.8.26.0000; 2053356-75.2020.8.26.0000; 2073165-51.2020.8.26.0000; 204241214.2020.8.26.0000; 2060855-13.2020.8.26.0000; 2055497-67.2020.8.26.0000; 2050733-38.2020.8.26.0000; $2064167-94.2020 .8 .26 .0000 ; \quad 2058939-41.2020 .8 .26 .0000 ; \quad 2074301-83.2020 .8 .26 .0000 ; \quad 2087756-$ 18.2020.8.26.0000; 2066742-75.2020.8.26.0000; 2066658-74.2020.8.26.0000; 2077233-44.2020.8.26.0000; $2075014-58.2020 .8 .26 .0000 ; \quad 2074285-32.2020 .8 .26 .0000 ; \quad 2085355-46.2020 .8 .26 .0000 ; \quad 2059490$ 21.2020.8.26.0000; 2077768-70.2020.8.26.0000; 2078346-33.2020.8.26.0000; 2084403-67.2020.8.26.0000; 2072517-71.2020.8.26.0000; 2082481-88.2020.8.26.0000; 2075861-60.2020.8.26.0000; 207249780.2020.8.26.0000; 2055698-59.2020.8.26.0000; 2056549-98.2020.8.26.0000; 2062149-41.2020.8.26.0000; $2065932-03.2020 .8 .26 .0000 ; \quad 2066680-35.2020 .8 .26 .0000 ; \quad 2069917-77.2020 .8 .26 .0000 ; \quad 2068150$ 04.2020.8.26.0000; 2072703-94.2020.8.26.0000; 2060198-71.2020.8.26.0000; 2059005-21.2020.8.26.0000; 2062340-48.2020.8.26.0000; $0006297-02.2020 .8 .26 .0000 ; \quad 1000012-43.2020 .8 .26 .0633$; $1015344-$ 44.2020.8.26.0053; 1000335-51.2020.8.26.0244; 1012331-36.2020.8.26.0506; 2080564-34.2020.8.26.0000; 2092348-08.2020.8.26.0000; e 1015074-20.2020.8.26.0053. Disponível em: $<$ https://esaj.tjsp.jus.br/cjsg/consultaCompleta.do?f=1> indicando no campo de pesquisa o número do recurso. Acessos em 29.05.20

BRASÍlIA. SUPREMO TRIBUNAL FEDERAL. . Painel de Ações COVID-19. Disponível em: https://ransparencia.stf.jus.br/single/?appid=615fc495-804d-409f-9b08-fb436a455451\&sheet=260e1 caef9aa-44bb-bbc4-9d8b9f2244d5\&theme=simplicity\&opt=currsel\%2Cctxmenu\&select=clearall. Acesso em: 15 fev. 2021

GIRARDI, Giovana. OMS declara pandemia de novo coronavírus; mais de 118 mil casos foram registrados. 2020. Disponível em: https://saude.estadao.com.br/noticias/geral,oms-declara-pandemia-de-novocoronavirus-mais-de-118-mil-casos-foram-registrados,70003228725. Acesso em: 15 fev. 2021

SÃO PAUlO (Estado). Comunicado $\mathrm{n}^{\circ}$ 69, de 15 de maio de 2020. . São Paulo, SP, Disponível em: https://www.tjsp.jus.br/Download/Portal/Coronavirus/Comunicados/ComunicadoCSM69-2020.pdf. Acesso em: 15 fev. 2021.

SÃO PAULO. TRIBUNAL DE JUSTIÇA DO ESTADO DE SÃO PAULO. (org.). Quem Somos. Disponível em: https://www.tjsp.jus.br/QuemSomos. Acesso em: 15 fev. 2021.

\section{Notes:}

Note 1. Brazil declared a Public Health Emergency of National Importance (Emergência em Saúde Pública de Importância Nacional - ESPIN), through the Ordinance $n^{\circ} 188 / \mathrm{GM} / \mathrm{MS}$; the Ministry of Health and the state governments recommended a series of measures to prevent the spread of the virus, with the main caveat to avoid agglomerations; in the state of São Paulo - among many other administrative measures - teleworking for the elderly, pregnant women and people with chronic respiratory diseases, heart disease, diabetes, hypertension or other conditions that depress the immune system was instituted; museums, libraries and cultural spaces were closed; public events have been suspended since the day 16.03.20; state schools were closed and classes suspended; finally, there is a restriction of access to public bodies, with regulation of the flow of people (according to State Decrees n ${ }^{\circ} 64.862$ e 64.864).

Note 2. In view of the seriousness of the situation experienced in the country, the Judiciary of São Paulo, in the case files of Case No. 1000012-43.2020.8.26.0633, of the Itanhaém / SP District, granted an injunction restricting the access of tourists to the municipalities of Mongaguá, Itanhaém, Peruíbe, Itariri and Pedro de Toledo, while the state of emergency persists; the 14th Court of the Public Finance of the Capital granted an injunction, in the public civil action $\mathrm{n}^{\circ}$ 1015344-44.2020.8.26.0053, authored by the Public Ministry, prohibiting religious cults in the Capital; in the Comarca de Iguape, case $\mathrm{n}^{\circ}$ 1000335-51.2020.8.26.0244, the Judiciary has determined the suspension of all non-essential activities and services, such as gyms, restaurants and commerce; the suspension of non-essential public services that cannot be performed through digital means or remote work; the ban on the entry of new guests into the hotel sector; among others; the Justice of the District of Ribeirão Preto/SP suspended, in the records of the case $n^{\circ} 1012331-36.2020 .8 .26 .0506$, the Municipal Decree $n^{\circ} 100 / 20$, which made social isolation more flexible, going against restrictions imposed by the Government in the face of the Covid-19 pandemic; in the same sense, the decision issued in case No. 2080564-34.2020.8.26.0000, of the District of Sertãozinho; the São Paulo Court of Justice has denied the request from the Municipality of Itararé, in the Civil Writ of Mandate No. 2092348-08.2020.8.26.0000, to resume normal activities; finally, following a request from the Union of Prison Agents of the State of São Paulo, he suspended visits to all prisons in the State, as can be seen in the Writ of Mandate No. 1015074-20.2020.8.26.0053. Accessed on May 29, 2020.

Note 3. It is noted that in recent past, Brazilian jurisprudence has added efforts to minimize the effects of mass incarceration, with the adoption of criteria, subsequently positivized, for the substitution of pre-trial detention (arts. 318 and 318-A of the Criminal Procedure Code ) and compliance with an open regime in a private residence (art. 117, Law No. 7,210 / 84). In this sense Habeas Corpus Coletivo n ${ }^{\circ} 143641$ available 
in: $<$ http://www.stf.jus.br/portal/cms/verNoticiaDetalhe.asp?idConteudo=370152> Access in: 04.06.20.

Note 4. Thirty (30) Habeas Corpus related to convicted persons were analyzed, of which 22 had their order dismissed and 08 had their order granted.

Note 5.As provided in art. 105, item I, item 'c', of the Constitution, whose wording states that "it is the Superior Court of Justice (I) to process and judge, originally ('c') habeas corpus, when the coorator or patient is any of the people mentioned in item 'a' (in common crimes, the Governors of the States and the Federal District, and, in these and those of responsibility, the judges of the Courts of Justice of the States and the Federal District, the members of the Courts of Accounts of States and Federal District, Regional Federal Courts, Regional Electoral and Labor Courts, members of Councils or Courts of Accounts of Municipalities jurisdiction, Minister of State or Commander of the Navy, Army or Air Force, except for the jurisdiction of the Electoral Justice ".

Note 6. Defined by the Doctrine as a technical impropriety the jurisprudential understanding of Courts, of which it is not known of habeas corpus whose thesis has not been submitted to the scrutiny of the co-authoritative authority.

Note 7. 64 decisions were analyzed, of which 08 (12.5\%) were rejected outright, that is, they did not know about the habeas corpus filed.

Note 8. Cases in which the merit of the petition was assessed, but denied the order.

Note 9. Cases in which the merits of the petition have not yet been assessed, but in a preliminary analysis, the request for freedom was rejected. In this situation, the deed will be sent for judgment by the collegiate body.

Note 10. Cases in which, even if the patient is in the risk group, the injunction was rejected, and the fact will be sent to the collegiate body for judgment.

Note 11. Cases judged where the order was granted.

Note: 12. Cases in which the injunction was granted and awaits the final judgment by the collegiate body.

Figure 1: In this field, 20 (twenty) Habeas Corpus, each square is equivalent to one action, to gauge the number of decisions by type of crime

Figure 2: In this field, 12 (twelve) Habeas Corpus, each square is equivalent to a crime-type, to gauge the number of favorable decisions

Figure 3: Indicates the type of results garanted by Superior Court of Justice on habeas corpus filled based on the pandemic argument and risks involved 